\title{
Growing Competition for Libraries
}

\author{
$\underline{\text { AUTHOR }}$ \\ Susan Gibbons \\ Director, LSTA-funded EBook Evaluation Project \\ \& \\ Digital Initiatives Librarian \\ University of Rochester \\ Rush Rhees Library \\ Rochester, NY 14627 \\ Phone: 716-275-6320 \\ Fax: 716-273-1032 \\ Email:sgibbons@rcl.lib.rochester.edu
}

KEYWORDS: Questia, Digital libraries, Academic libraries, Online services, Library marketing

\begin{abstract}
$\underline{\text { ABSTRACT }}$
This article begins with an analysis of Questia's online collection of digitized books and articles. Although the collection is not found to be a strong one, Questia's strength lies in its ability to utilize the digital format to overcome many of the barriers and inconsistencies that undergraduate students encounter in a traditional brick-andmortar academic library. Librarians can learn a lot from Questia and perhaps use that knowledge to improve their own services.
\end{abstract}

\section{INTRODUCTION}

On January 22, 2001, amid a great media buzz, Questia opened its doors on a collection of over 35,000 digital books. Troy Williams, CEO and founder of Questia Media America, Inc., dreamed up the idea of a subscription-based, online digital library after experiencing firsthand the disparities between the libraries of the poorest and wealthiest higher education institutions. Questia is meant to be an equalizer, providing all students, regardless of which college they enroll, unfettered access to the same library resources. If Questia reaches its self-imposed collection goal of 250,000 titles by 2003, then, according to Williams, Questia will be larger than 80 percent of all U.S. academic libraries.

Questia digitizes the majority of books and articles themselves, using XML and complying with the Open eBook Standard. In addition to the traditional author, title and subject searches, the entire online library is searchable at a full-text level. But Questia is more than an online collection of books and articles, because it offers a suite of tools to facilitate the writing of term papers. Backed by significant marketing research, the 
Questia online service was designed to be very appealing to undergraduate students. But what exactly is in this digital library, and what can librarians learn from Questia and similar commercial digital libraries in order to improve their own services?

\section{QUESTIA'S COLLECTION}

On the whole, Questia pales in comparison to almost any academic library, both in quantity and quality. When Questia opened its doors in January, it had a collection of 35,000 monographs, covering twenty-eight social sciences and humanities fields. An immediate impression of the collection is that it is quite dated. A random sampling of 100 monographs had an average publication date of 1973, with only one title published after 1999. Although Questia has attributed the age of its collection to its emphasis on classic, seminal texts of the humanities and social sciences, as Mick O'Leary points out, there can be little retrospective value to many of the titles (O'Leary, 2001, p. 14). Carol Ann Hughes, Director of Collections Management at Questia, makes the point that obsolescence of monographs is really in the eye of the user and that age or lack of use should not be the only factors in judging the value of a book (Hughes, 2001). However, when a collection contains only 35,000 monographs, should not the shelves first be populated by those texts that have demonstrative value? While all books have value, all books do not have equal value, and therefore do not warrant equal weight within such a small collection.

Questia’s goal is to “develop a collection that provides substantial coverage of high quality information for most post-secondary core curriculum courses” [1]. As such, it is important to have a strong core collection of primary sources. O'Leary correctly draws attention to the absence of several important primary sources, such as Midsummer Night's Dream, A Tale of Two Cities and A Streetcar Named Desire, as well as most of the Pulitizer Prize-winning nonfiction titles of the past 20 years (O'Leary, 2001, p. 14). Numerous critical secondary courses are absent as well. For instance, the medieval history collection lacks all of the seminal works by renown, prolific historians Peter Robert Lamont Brown and Georges Duby, and all but one title by the late Richard E. Sullivan. Questia’s online library of books appears to be haphazard and very uneven, offering no real critical mass in any of its twenty-eight subject areas.

Journal articles were added to Questia's online library in April. As with the monographs, this compilation of articles is very dated and considerably uneven. A sampling of 100 journal articles shows that the majority were published between 1994 and 1998, with an average publication date of 1994. The dates ranged from 1980 to only five titles from 2000 and a single title from 2001. Within this sampling, only twenty-five unique journals were represented. A surprising two-thirds of the articles were published by Lawrence Erlbaum Associates, resulting in nearly $40 \%$ of the article collection falling within the category of psychology. Unfortunately, psychology is not a strength of Questia's monographs, so the rest of the collection does not complement this large number of psychology articles. 
Overall, it would be very difficult to write a quality research paper based solely on what is in Questia's collection. Questia has countered that its online library was intended to complement and support the traditional brick-and-mortar library, "by giving [students] another tool to help perform their research" [2]. However, as I will address later in this article, I believe this message to be in part disingenuous.

With all this said, Questia cannot and should not be dismissed. Although their collection is not a very strong one, there is a great deal that Questia is doing right. More importantly, there is much that librarians can learn from Questia's business model.

\section{WHAT DO COLLEGE STUDENTS WANT FROM A LIBRARY?}

The reality is that college students live in a $24 \times 7$ world and seek out services that cater to this lifestyle. The vast majority of libraries have shut their doors by midnight, at just the time when many students are beginning that last-minute push to finish a term paper. Procrastination is inevitable. What research materials are available to students after midnight? Although they may find some full-text articles via the library's online databases, article citations and abstracts, and the call numbers of relevant books are all useless, when the materials are completely inaccessible behind locked doors. Questia, on the other hand, offers full-text articles and books around the clock-- the doors of this virtual library never close. Questia knows its users well and caters to their lifestyle, whereas most libraries do not. And many more students than we care to believe will sacrifice quality of information for ease of accessibility.

A frustration of a great many students is to locate a book that appears to be highly pertinent to their research, only to find that the book is missing from the stacks, checked out to a professor for the next 6 months or on reserve and therefore only available for limited periods of time. These barriers to resources, in many cases unavoidable in a traditional library, are nowhere to be found in Questia's digital library. Every item in Questia's collection, down to the single page, is accessible to an unlimited number of users, simultaneously. This is a definite improvement over netLibrary's digital library which restricts access to a title to one user per library subscription. A further source of frustration among students is to encounter differing levels of document accessibility from electronic resources. Why should some articles be full-text, while others are only abstracts or nothing more than citations? The complications and technicalities of copyrights that create this situation are, for the most part, irrelevant to students; they simply want the information that is tantalizingly locked behind an abstract or citation. There are no such teases in Questia because everything is full-text.

In the age of Amazon.com, where everything from muffin tins to wide-screen TVs can be purchased in one spot, college students live in a world of one-stop shopping. Their expectations are unmet when they arrive in the library and discover that a search in the library's online catalog will only retrieve books. Not just one but possibly several databases and indexes must be consulted in order to locate relevant articles. This makes no logical sense to anyone except a librarian, and the historical circumstances and customs that led to this situation are immaterial. Questia has tossed this confusing library 
paradigm aside and combined monographs and journal articles into a single database. A search in Questia results in all related materials, regardless of format and origin.

Questia also capitalizes on the fact that the majority of encounters between undergraduate students and research materials are for the express purpose of writing a term paper. As a result, a suite of helpful tools has been built into Questia enabling students to write the paper as they come upon the materials. For instance, portions of the texts can be cut and pasted into any word processor, and Questia creates the citation and bibliography automatically, in any one of five formats, including MLA and Chicago Manual of Style. Moreover, Questia's research tools allow the student to personalize the text with annotations, highlighting and bookmarkings. This is quite a different experience from that of a traditional brick-and-mortar library. Most libraries discourage students from writing their term papers in the building by offering only a very limited number of public computer terminals, many of which deliberately do not offer any word processing programs. Students are expected to locate their research materials in one setting, but use and engage them in another. This is a frustrating inconvenience to students and one that Questia overcomes.

Questia's website is very slick and appealing. More importantly, it is free of all of the library jargon that frequently clutters the websites of academic libraries. A study by Lesley Moyo and Ashley Robinson of Pennsylvania State University confirmed that the use of professional, library jargon on a website had a significant, negative impact on the usability of that site (Moyo \& Robinson, 2001). In spite of the fact that this conclusion is a rather obvious one, Moyo and Robinson routinely found library jargon, such as "interlibrary loan", "collection services" and "user education" on the websites of the twenty major academic libraries that they studied. Questia's website is refreshingly jargon free. You will not find the terms "boolean”, "monograph" or "serial” anywhere in Questia.

\section{IMPORTANCE OF MARKETING}

Ample market research has led Questia to a firm understanding of its target market, the average undergraduate student. Consequently, Questia’s online library caters itself to the lifestyles of students. It takes full advantage of its digital format to overcome many of the inconsistencies and barriers that students encounter in a traditional library. But perhaps even more impressive than Questia's services are its marketing techniques.

Every student who watched the NCAA Men’s Basketball Final Four probably saw Questia's commercial at least once. The commercial shows a student, drenched in sweat and obviously in great distress over the upcoming deadline for a term paper. The message conveyed-- "Paper due? Stop Sweating” because Questia is here to help.

Additionally, students are receiving a flood of colorful, slick flyers touting the laurels of Questia's “innovative, scholarly and indispensable” collection. Promotional prizes, including a laptop computer and PDA, are available just for visiting Questia’s website. Understanding that students may not have or want to spend \$19.95 for a month's subscription, Questia will email a student's parents, requesting that they purchase the subscription on behalf of their child. 
Often the most persuasive marketing message is the one that comes from peers. Realizing this, Questia is recruiting students to push their product. This spring, emails were sent to students by Questia, who was seeking “one special and dynamic individual to help spread the word about the benefits of Questia's research service.” Questia's student representatives are asked to be "ambassadors for Questia” on campus by distributing promotional materials and staffing a Questia information table. Moreover, in exchange for $\$ 100$, the student representatives conduct reports and market surveys about their campuses. Questia has even used the job application process to obtain valuable marketing information. The application process requires providing the names and contact information for two close friends and writing an essay answering one of the following three questions: What is your favorite website and why?; What are your three most favorite and least favorite things about what Questia summarizes in its online product tour and why?; or, If a new location of your favorite restaurant opened near campus, how would you promote it to your fellow students? Questia never misses an opportunity to learn more about its market.

How many academic libraries have one or more trained marketing experts on staff? How many academic libraries market their collections and services frequently and with the pizzazz of a "Got Milk?" campaign? A safe guess would be very few. Unfortunately, too many libraries are complacent, believing that the value of their collections and services is intrinsic and obvious to all their patrons. The motto "if you build it, they will come" should not be applied to a library collection, particularly when there are barriers, such as closed doors, and inconsistencies, including the inability to search for books and articles simultaneously. Questia is keenly aware of the value of a good marketing campaign and has launched a media blitz aimed directly at the undergraduate college student. Unless libraries do the same, the Questia message may be the only message students hear.

\section{WHAT THREAT DOES QUESTIA POSE?}

Carol Ann Hughes is quite correct in her assessment that as the number of information service suppliers increase "the role of the library as primary aggregator and purveyor of content to its community is less and less unique” (2000). Libraries now have competition. The fact that for-profit information providers could eventually replace academic libraries is not really the issue. The laws of a competitive marketplace dictate that unless your services are relevant and vital, you will be supplanted. However, with the present, limited state of its digital library collection, the danger that Questia poses is not to libraries as much as it is to students, professors and the educational mission of colleges and universities.

The spin that Questia puts in its marketing to librarians is that it is providing an online research service that complements and supports the collection of a traditional, academic library. However, this message is not conveyed in Questia's marketing to students and publishers: 
Students want flexibility. Questia is accessible 24 hours a day, seven days a week- from anywhere in the world. Students want ease. Questia is Point. Click. Read. Write. Learn. And with multiple papers due, students want it fast and efficiently. Which pretty much sums up the Questia service- the one-stop, comprehensive source [3].

If students believe that Questia is a "one-stop, comprehensive source," then it is the quality of the education of these students that will suffer. If Questia's collection reaches its self-imposed goal of 250,000 titles, then students may very well be able to obtain much of the relevant information that they would need to write a quality term paper. However, this is not possible with the current state of Questia's collection, and there is nothing in its promotional marketing or on its website to warn students of that fact. For $\$ 19.95$ per month, many students believe that they are purchasing easy access to all of the relevant information that they need to write a quality term paper. This is not the case and somehow this warning needs to make its way to students.

\section{CONCLUSION}

In May, Questia let go approximately half of its workforce. Founder, Troy Williams, attributed the reduction to the slower pace at which books will be added to Questia's collection (Fowler, 2001). This would suggest that Questia's self-imposed goal of a collection of 250,000 titles by 2003 will not be reached. And with little more than 1,000 paid subscribers, Questia appears to have misjudged the willingness of students to trim their meager budgets by $\$ 19.95$ per month. However, although Questia may fail, others are waiting in the wings. On example is ebrary, which is set to launch its "rich online library of copyrighted books, journals, periodicals and more" this fall, using a payper-use, rather than subscription, model [4].

The fast-paced, deadline-oriented lifestyle of students directs them towards services that provide information quickly and easily. Questia knows this and caters to this vulnerability of students. Questia should serve as a warning, not just to librarians, but also to all educators, that now, more than ever, we must stress the importance of critically analyzing information resources. Moreover, libraries need to ensure that their patrons understand the value that librarians add to a collection. An academic library's collection has been tailored to the institution's academic curriculum, which is quite different from Questia's “one size fits all” model. Furthermore, nothing can replace the real-time, human-to-human communication and assistance that students receive from a library's staff. This important interaction cannot be duplicated by technology and $\$ 19.95$ per month. This is the message that undergraduate students need to be hearing from their libraries. Hopefully, a little healthy competition from services such as Questia will serve to make academic libraries all the better. 


\section{NOTES}

1 http://www.questia.com

2 http://www.questia.com/faq.jsp

3 Questia’s Media Guide, 8/00

4 http://www.ebrary.com

\section{REFERENCES}

Fowler, Tom. (2001) “Online college library and research firm slows pace, reduces staff by almost half”, The Houston Chronicle, May 9, 2001, Business Section, p. 1.

Hughes, Carol Ann. (2001) “The Myth of “Obsolescence”: the Monograph in the Digital Library”, portal: Libraries and the Academy, Vol. 1, No. 2, pp. 113-119.

Ibid. (2000) "Information Services for Higher Education: A New Competitive Space”, DLib Magazine, Vol. 6, No. 12, December 2000.

Moyo, L. and Robinson, A. (2001) "Library Jargon as a factor in Information Design for Web Usability: Survey Report (Summary)”, Computers in Libraries 2001: Collected Presentations, March 2001, pp. 157-165.

O’Leary, M. (2001) “Questia’s tale on the digital library”, Information Today, April 2001, pp. 14-15. 